\title{
Article
}

\section{The Effect of Different Fertilization Regimes on Yield, Selected Nutrients, and Bioactive Compounds Profiles of Onion}

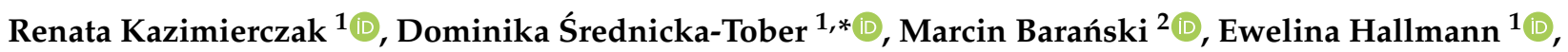

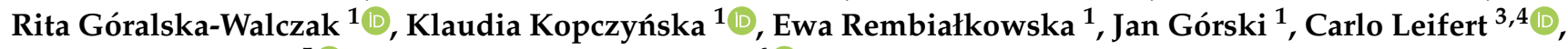 \\ Leonidas Rempelos ${ }^{5}$ and Stanisław Kaniszewski ${ }^{6}$ (D)
}

1 Department of Functional and Organic Food, Institute of Human Nutrition Sciences, Warsaw University of Life Sciences, Nowoursynowska 159c, 02-776 Warsaw, Poland; renata_kazimierczak@sggw.edu.pl (R.K.); ewelina_hallmann@sggw.edu.pl (E.H.); rita_goralska_walczak@sggw.edu.pl (R.G.-W.); klaudia_kopczynska@sggw.edu.pl (K.K.); ewa_rembialkowska@sggw.edu.pl (E.R.); jangorski17@wp.pl (J.G.)

2 Laboratory of Neurobiology, Nencki Institute of Experimental Biology, Polish Academy of Sciences, Pasteura 3, 02-093 Warsaw, Poland; m.baranski@nencki.edu.pl

3 Department of Nutrition, Institute of Basic Medical Sciences, University of Oslo, 0372 Oslo, Norway; carlo.leifert@scu.edu.au

4 Southern Cross Plant Science, Southern Cross University, Military Rd., Lismore, NSW 2480, Australia

5 School of Agriculture, Food and Rural Development, NEFG, Newcastle University, Newcastle upon Tyne NE1 7RU, UK; leonidas.rempelos@ncl.ac.uk

Citation: Kazimierczak, R.; Średnicka-Tober, D.; Barański, M.; Hallmann, E.; Góralska-Walczak, R.; Kopczyńska, K.; Rembiałkowska, E.; Górski, J.; Leifert, C.; Rempelos, L.; et al. The Effect of Different Fertilization Regimes on Yield, Selected Nutrients, and Bioactive Compounds Profiles of Onion. Agronomy 2021, 11, 883. https:// doi.org/10.3390/agronomy11050883

Academic Editor: Sean Smukler

Received: 19 March 2021

Accepted: 27 April 2021

Published: 29 April 2021

Publisher's Note: MDPI stays neutral with regard to jurisdictional claims in published maps and institutional affiliations.

Copyright: (c) 2021 by the authors. Licensee MDPI, Basel, Switzerland. This article is an open access article distributed under the terms and conditions of the Creative Commons Attribution (CC BY) license (https:/ / creativecommons.org/licenses/by/ $4.0 /)$.
6 The National Institute of Horticultural Research, Konstytucji 3 Maja 1/3, 96-100 Skierniewice, Poland; stanislaw.kaniszewski@inhort.pl

* Correspondence: dominika_srednicka_tober@sggw.edu.pl; Tel.: +48-225-937-035

Abstract: Here we report the results of a three-year replicated field trial on the effects of novel cloverand alfalfa-based fertilizer products (Ekofert ${ }^{\circledR} \mathrm{K}$ and Ekofert ${ }^{\circledR} \mathrm{L}$ ), with the input levels equivalent to 120,180 , or $240 \mathrm{~kg} \mathrm{~N} \mathrm{ha}^{-1}$, on the yield and selected sensory and nutritional quality parameters of onion. The study showed that Ekofert fertilizer applied at all three levels produced similar or higher yields than the standard fertilization regimes used in conventional farming in all three seasons. Significant differences in onion composition profiles between fertilization treatments were detected within individual seasons; however, due to substantial interseasonal variation, no consistent differences could be detected between (i) mineral $\mathrm{N}$ and Ekofert fertilizer treatments, (ii) the two different Ekofert products, and (iii) contrasting Ekofert input levels. Results demonstrate that cloverand alfalfa-based pelleted organic fertilizer products are a suitable alternative for intensive organic field vegetable production.

Keywords: onion (Allium cepa L.); flavonoid compounds; sugars; organic acids; vitamin C; organic fertilization; mineral fertilization

\section{Introduction}

There is increasing concern about negative impacts of agrochemicals, such as mineral NPK-fertilizers and synthetic chemical pesticides, on the environment, biodiversity, and food quality and safety [1]. Organic farming standards therefore prescribe the use of organic fertilizers and non-chemical, preventative management-based crop protection methods as an alternative, to reduce the use of agrochemical inputs in agriculture [2]. The use of organic fertilizers is also recommended due to their positive impact on soil physical, chemical, and biological properties. Organic fertilizers have been shown to increase soil biological activity and biodiversity, structural stability, water retention, and cation exchange capacity [3]. However, there has been concern about the microbiological safety of applying organic fertilizers such as animal manure directly prior to planting, especially in case of crops that are consumed raw (e.g., salat vegetables and fruit) [4]. The use of such untreated manure immediately prior to planting is therefore prohibited in organic farming. As a result, there is a need to develop alternative, easy-to-use fertilizers for organic 
field vegetable production, that can be applied at planting, provide a balanced supply of nutrients, and pose no potential food safety risks [4]. Pelleted fertilizers made from legume crops are thought to serve as a suitable alternative, especially considering that many organic arable and horticultural producers grow fertility-building legume leys as part of their rotations $[5,6]$. However, there is very limited information on the effectiveness of different types of pelleted legume-based fertilizers for many horticultural crops. Moreover, although the release of nutrients from such fertilizers through the mineralization by soil microorganisms is thought to be slower than from mineral fertilizer inputs, there is no detailed information on the nutrient release characteristics and nutrients availability over a typical growth period of particular vegetable crops [7-9]. It is therefore important to optimize crop-specific fertilization regimes (e.g., fertilizer type and input level) in terms of yield, but also in terms of the potential knock-on effects on nutritional composition.

In this context, the present study aimed to assess the effects of two new granulated organic fertilizers, made from dried biomass of red clover and alfalfa, on the yield and concentrations of a number of sensory and bioactive compounds in a selected vegetable crop-onion (Allium cepa L.). The effects of organic fertilizers were also compared to standard mineral fertilization protocols used in conventional production (as a benchmark for yield potential) and a 'no fertilizer input' control.

Onion crop is known to require substantial amounts of nutrients (especially nitrogen) to be applied before planting. Both the fertilizer input level and its application methods were previously shown to affect the yields and the nutritional composition of onion [10]. Onion is also known to contain phytochemicals linked to positive nutritional and health impacts [11]. Onion extracts were previously shown to support the circulatory system by causing reduction of blood viscosity, and thus preventing blood clots [12]. Antiinflammatory, anticancer, anti-allergic, bactericidal, and bacteriostatic properties of onion are also well-documented [13]. Most of the mentioned health-promoting effects of onions have been attributed to the organic sulfur compounds responsible for the characteristic flavor of onions, as well as to flavonoids, such as quercetin and its derivatives [14]. Numerous studies have linked antioxidant properties of flavonoids present in onion bulbs, and analyzed within the present study, with a lower risk of developing certain cancers and cardiovascular diseases [7,15-19]. Flavonoids are present in onion plants in relatively high concentrations, either conjugated to sugars, or in the form of aglycons [20]. The biosynthesis and concentrations of flavonoids in onions are known to be dependent on both genetic and agronomic factors, including fertilization [21].

\section{Materials and Methods}

\subsection{Study Design and Research Material}

The field experiment was carried out in three consecutive agronomic/growing seasons (2012, 2013, and 2014) at the Institute of Horticulture in Skierniewice in central Poland $\left(51^{\circ} 57^{\prime} \mathrm{N} 20^{\circ} 80^{\prime} \mathrm{E}\right)$. Every year of the experiment, onions of the early variety Alonso F1 (Bejo Zaden, The Netherlands), grown from seedlings, were planted in the field on sandy loam soil (68\% sand $0.1-1 \mathrm{~mm}$ grain, $19 \%$ silt $0.1-0.2 \mathrm{~mm}$, and $13 \%$ clay $<0.02 \mathrm{~mm}$; $\mathrm{pH}$ 6.5; organic matter content 1.16\%) in mid-April in two field replicates (size of a single replicate plot: $10 \mathrm{~m}^{2}$ ). It was a static experiment, carried out on the same field each year. Fertilizer inputs used prior to onion cultivation included $25 \mathrm{t} \mathrm{ha}^{-1}$ of compost.

Alonso F1 onions are spherical, covered with a strong, straw colored husk. According to the information provided by the breeding company this cultivar is characterized by high yielding under various conditions.

The average monthly temperatures and rainfall conditions in 2012-2014 are presented in Figure 1. The total amount of precipitation during the onion growing season (April-August) was $302 \mathrm{~mm}$ in 2012, $438 \mathrm{~mm}$ in 2013, and $399 \mathrm{~mm}$ in 2014. The average temperature during the onion growing season was $15.6{ }^{\circ} \mathrm{C}$ in $2012,15.2{ }^{\circ} \mathrm{C}$ in 2013 , and $15.6^{\circ} \mathrm{C}$ in 2014 . 


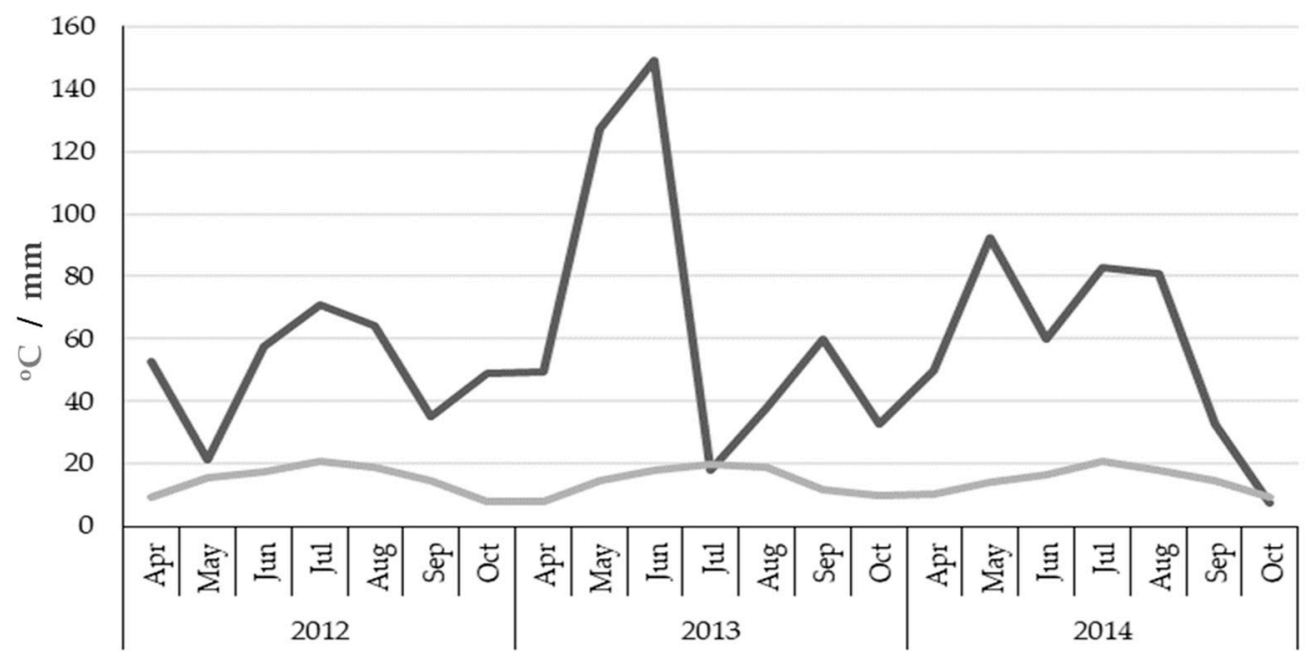

Figure 1. The average monthly temperature $\left({ }^{\circ} \mathrm{C}\right.$, light grey line) and total monthly rainfall (mm, dark line) during the vegetative growth periods in the years 2012-2014 (April 2012-October 2014).

The experimental treatments included an application of the commercially available Ekofert ${ }^{\circledR} \mathrm{K}$ and Ekofert ${ }^{\circledR} \mathrm{L}$ (Poltops, Żagań, Poland) pelletized organic fertilizers from red clover (K for "koniczyna" in Polish) (N-P-K ratio 3.1-0.2-3.0 of dry matter) and alfalfa (L for "lucerna" in Polish) (N-P-K ratio 3.5-0.2-3.1 of dry matter) respectively. Both experimental fertilizers were applied in onion cultivation as a pre-planting treatment, using fertilizer input levels equivalent to 120,180 , and $240 \mathrm{~kg}$ total $\mathrm{N} \mathrm{ha}^{-1}$. The mineral nitrogen $(\mathrm{N})$ fertilizer control treatments consisted of the standard conventional mineral fertilization (ammonium nitrate) at a dose of $100 \mathrm{~kg} \mathrm{~N} \mathrm{ha}^{-1}$ applied as a single pre-planting treatment, or in two doses of $50 \mathrm{~kg} \mathrm{~N}^{-1}$ each with no-fertilization protocol. Due to the low nitrogen availability for plants, the dose of $120 \mathrm{~kg} \mathrm{~N} \mathrm{ha}^{-1}$ of organic fertilizer was considered as an equivalent of $100 \mathrm{~kg} \mathrm{ha}^{-1}$ of mineral nitrogen (which is a recommended dose in conventional onion cultivation). The agronomic protocols used for plots of the nine fertilization treatments were identical, but the timing of management practices (e.g., planting, weed control, harvest) differed between years depending on weather conditions. Onion bulbs from all treatments were harvested at the peak of physiological maturity (when about $80 \%$ of the plants had broken chives and about $50 \%$ of the leaves were green), and the fresh weight yield was determined at harvest.

\subsection{Chemical Analyses}

Samples from nine fertilization treatments, each in two field replications, were tested for the content of dry matter, total sugars, reducing sugars, organic acids, vitamin C, and flavonoids in the laboratory of the Chair of Organic Food at the Warsaw University of Life Sciences, Poland.

The dry matter was determined using a gravimetric method according to the Polish standard (Polish Norm PN-EN 12145 2001). Samples of the onion bulbs were dried (48 h, $105^{\circ} \mathrm{C}$, constant pressure) using a Dryer KC-65 (Premed, Marki, Poland) with a free air circulation. The dry matter content was expressed as a percentage of the fresh material [22]. Before further analyses, all samples were grounded and lyophilized using a freeze-dryer (LabConco Corporation, Kansas City, MO, USA) at the temperature of $-40^{\circ} \mathrm{C}$ and pressure of $0.08 \mathrm{mBar}$. The dried samples were then milled (A-11 laboratory mill, IKA ${ }^{\circledR}$-Werke, Staufen im Breisgau, Germany) and stored at $-80^{\circ} \mathrm{C}$ until further analyses.

Total and reducing sugars were determined as previously described by Hallmann et al. (2017) using the Luff-Schoorl method [23]. Organic acids assessment was conducted by neutralization of the total acids content in the water solution. The solution with electrodes was titrated with sodium hydroxide $(0.1 \mathrm{M})$ until reaching a $\mathrm{pH}$ of 8.0. Total acidity was calculated as previously described by Hohen et al. [24]. The content of vitamin C was 
measured using titration method described in the Polish standard (Polish Norm PN-A75101-11: 1990) [25].

Flavonoids content (quercetin-3-O-rutinoside, quercetin-3-O-glucoside, myricetin, quercetin, and kaempferol) was analyzed using the high performance liquid chromatography (HPLC) method. The freeze-dried samples $(50 \mathrm{mg})$ were mixed with $1 \mathrm{~mL}$ of $80 \%$ methanol and $1 \%$ ascorbic acid, and incubated in an ultrasonic bath $\left(15 \mathrm{~min}, 30^{\circ} \mathrm{C}\right.$, $5.5 \mathrm{kHz}$ ). After the incubation samples were centrifuged twice $(5000 \mathrm{rpm}, 10 \mathrm{~min}$ and $12,000 \mathrm{rpm}, 5 \mathrm{~min}$ ) and $100 \mu \mathrm{L}$ was used for the HPLC analysis with the Synergi Fusion-RP $80 \mathrm{i}$ column $(250 \times 4.60 \mathrm{~mm})$ (Phenomenex Inc., Torrance, CA, USA) and HPLC equipment, including two LC-20AD pumps, a CBM-20A controller, a SIL-20AC column oven, and an UV/Vis SPD-20 AV spectrometer (Shimadzu, USA Manufacturing, Inc., Canby, OR, USA). The flavonols were separated under gradient conditions with a flow rate of $1 \mathrm{~mL} \mathrm{~min}{ }^{-1}$. Two gradient phases were used: $10 \%(\mathrm{v}: \mathrm{v})$ acetonitrile and ultrapure water (phase A) and 55\% (v:v) acetonitrile and ultrapure water (phase B). The phases were acidified with ortho-phosphoric acid ( $\mathrm{pH}$ 3.0). The total time of the analysis was $38 \mathrm{~min}$. The phase-time program was as follows: $1.00-22.99 \mathrm{~min}, 95 \%$ phase A and $5 \%$ phase B; $23.00-27.99 \mathrm{~min}, 50 \%$ phase $A$ and $50 \%$ phase $\mathrm{B} ; 28.00-28.99 \mathrm{~min}, 80 \%$ phase $\mathrm{A}$ and $20 \%$ phase B; and 29.00-38.00 min, 95\% phase A and 5\% phase B. The wavelength of detection was $370 \mathrm{~nm}$ [26]. All laboratory analyses within the study were done in duplicate.

\subsection{Statistical Analyses}

All statistical analyses of the data were carried out in R statistical environment [27]. In order to investigate the effect of cultivation year and fertilization treatment on measured parameters, two-way ANOVAs were derived from a linear mixed-effects model [28], which included the cultivation year and fertilization treatment as main factors, and the replicate as a random factor. The normality of the residuals of all models was tested using QQ-plots. Differences between the fertility treatments within each cultivation year were additionally tested using Tukey contrasts in the general linear hypothesis testing (glht) function of the 'multcomp' package in R [29]. A linear mixed-effects model was used for the Tukey contrasts, containing a treatment main effect, with the random error term specified as described above. A principal component analysis (PCA) was performed to explore possible differences and similarities in the composition of onions grown under different combinations of organic and mineral fertilization. The PCA was performed using the 'prcomp' function, and the plots were generated with the 'ggbiplot' package. Additionally, Pearson's product-moment correlation analyses were carried out to identify potential linear associations between the concentrations of individual and groups of the analyzed compounds in the onion samples, using the 'cor' function and visualized using the 'corrplot' package.

\section{Results and Discussion}

\subsection{Onion Bulb Yield}

Table 1 shows the yield of Alonso F1 onion bulbs grown with different fertilization regimes in three consecutive years. Yields from the nine treatments ranged from 44 to $66.1 \mathrm{t} \mathrm{ha}^{-1}$, which overall represent higher values than those reported in previous studies (between 31 and $42 \mathrm{t} \mathrm{ha}^{-1}$ ) [30-33]. The two-factor ANOVA detected a significant interaction between the effects of season and fertilization on the onion yield $(p<0.001)$. Therefore we carried out a separate one-factor ANOVA to compare the effects of fertilization treatments separately in the three different seasons (Table 1). Onion yields in fertilized plots were higher than those in the non-fertilized control plots. At the same time, no significant differences were detected between the non-fertilized control and (a) the single N-dose mineral fertilizer treatment in all three years and (b) the Ekofert L 120 treatment in year 1 only (Table 1). In all three years, the Ekofert treatments resulted in higher yields than the single-N dose mineral treatment, but in similar yields when compared to the split $\mathrm{N}$-dose mineral treatment (Table 1). It should also be pointed out that the intermediate input level 
Ekofert treatments (K180 and L180) produced significantly higher yields than the split $\mathrm{N}$-dose mineral fertilizer treatment in 2014 (Table 1). This clearly demonstrates that legume crop-based organic fertilizer products can deliver the same and possibly slightly higher yields when compared to the recommended split $\mathrm{N}$-dose mineral fertilization regimes in onions.

Table 1. The yield $\left(\mathrm{t} \mathrm{ha}^{-1}\right)$ of onion cultivated in different fertilization regimes. Data are presented as means.

\begin{tabular}{cccc}
\hline Fertilization Regime $^{\mathbf{1}}$ & $\mathbf{2 0 1 2}$ & $\mathbf{2 0 1 3}$ & $\mathbf{2 0 1 4}$ \\
\hline control N 0 & $61.2 \mathrm{~b} 2$ & $45.9 \mathrm{~d}$ \\
control N 100 & $62.0 \mathrm{~b}$ & $25.0 \mathrm{c}$ & $51.0 \mathrm{~cd}$ \\
control N 50 + 50 & $78.2 \mathrm{a}$ & $28.1 \mathrm{bc}$ & $67.3 \mathrm{~b}$ \\
Ekofert K 120 & $74.8 \mathrm{a}$ & $36.3 \mathrm{ab}$ & $63.3 \mathrm{bc}$ \\
Ekofert K 180 & $76.6 \mathrm{a}$ & $36.6 \mathrm{ab}$ & $81.8 \mathrm{a}$ \\
Ekofert K 240 & $78.4 \mathrm{a}$ & $39.1 \mathrm{a}$ & $65.8 \mathrm{~b}$ \\
Ekofert L 120 & $71.6 \mathrm{ab}$ & $30.2 \mathrm{a}$ & $65.2 \mathrm{~b}$ \\
Ekofert L 180 & $75.8 \mathrm{a}$ & $36.4 \mathrm{ab}$ & $83.7 \mathrm{a}$ \\
Ekofert L 240 & $78.0 \mathrm{a}$ & $38.7 \mathrm{a}$ & $72.3 \mathrm{ab}$ \\
\hline
\end{tabular}

\footnotetext{
${ }^{1}$ Fertilization: control N 0 (no input), control N 100 (mineral fertilizer at $100 \mathrm{~kg} \mathrm{~N} \mathrm{ha}^{-1}$ ), control N $50+50$ (mineral fertilizer at $2 \times 50 \mathrm{~kg} \mathrm{~N} \mathrm{ha}^{-1}$ ), Ekofert K 120/180/240 (red clover pellets at 120, 180, or 240 kg N ha ${ }^{-1}$ ), Ekofert L 120/180/240 (alfalfa pellets at 120, 180, or $240 \mathrm{~kg} \mathrm{~N} \mathrm{ha}^{-1}$ ); ${ }^{2}$ Values in columns followed by different small letters $(\mathrm{a}-\mathrm{d})$ are significantly different at the $5 \%$ level of probability (Tukey's test).
}

These results are consistent with a similar study with celeriac [34], where Ekofert K 180 and 240 resulted in a higher marketable yield, while Ekofert K 120 resulted in the similar yield when compared to a single-dose N 100 treatment.

It should be pointed out that crop yields were substantially lower in 2013 and this was most likely due to climatic conditions being more favorable for onion crops in 2012 and 2014. As shown in Figure 1, both temperature and rainfall were similar in 2012 and 2014, whereas in 2013 the substantially higher rainfall recorded in May and June may have had a negative effect on plant growth and yield.

Similar results were also reported by Yassen and Khalid (2009) [35], who found that a mixture of farmyard and chicken manure resulted in the higher onion yields when compared with a mineral NPK fertilizer control treatment including a single-dose preplanting application of $146.4 \mathrm{~kg} \mathrm{~N} \mathrm{ha}^{-1}$. Yoldas et al. (2011) [31] also reported a positive effect of cattle manure on the total onion bulbs yield. At the same time, the other yield parameters measured in their study (i.e., number of bulbs, bulb height, flesh thickness, number of shoot tips, and number of dried leaves) were not significantly affected by fertilization. Spiess et al. (2011) [36] also reported that organic fertilizers had a promoting impact on the yields of different field crops. They recorded higher yields when applying organic fertilizer (farmyard manure) in comparison to the use of mineral or mixture of organic and mineral fertilizers.

\subsection{Nutritional Composition Parameters}

Principal component analysis (PCA) of crop composition data clearly demonstrated that the climatic differences between the three growing seasons resulted in a clearer separation of results and explained a larger proportion of the variation than fertilization treatments (Figure 2). 
(a)

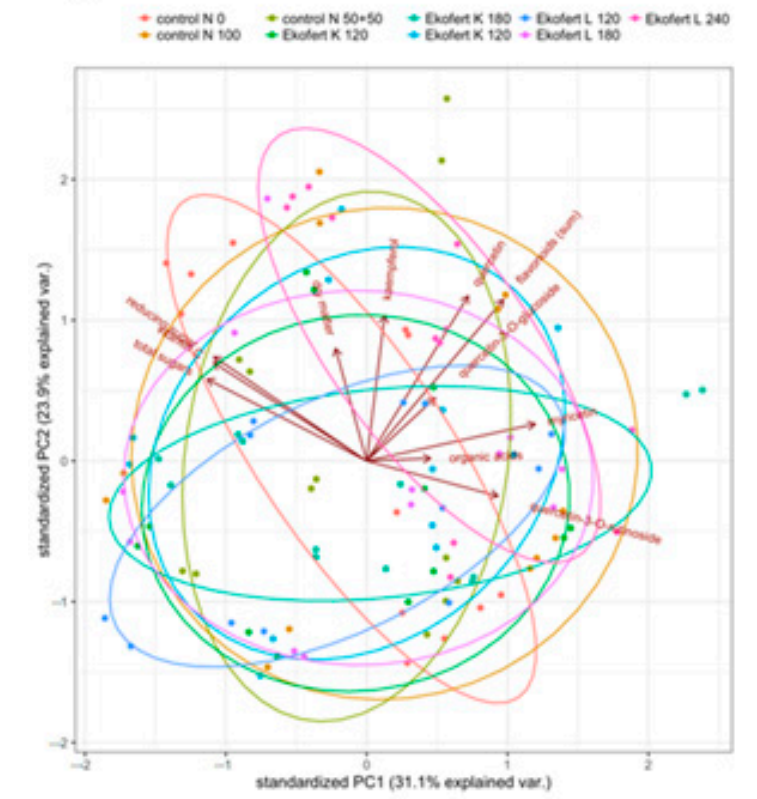

(b)

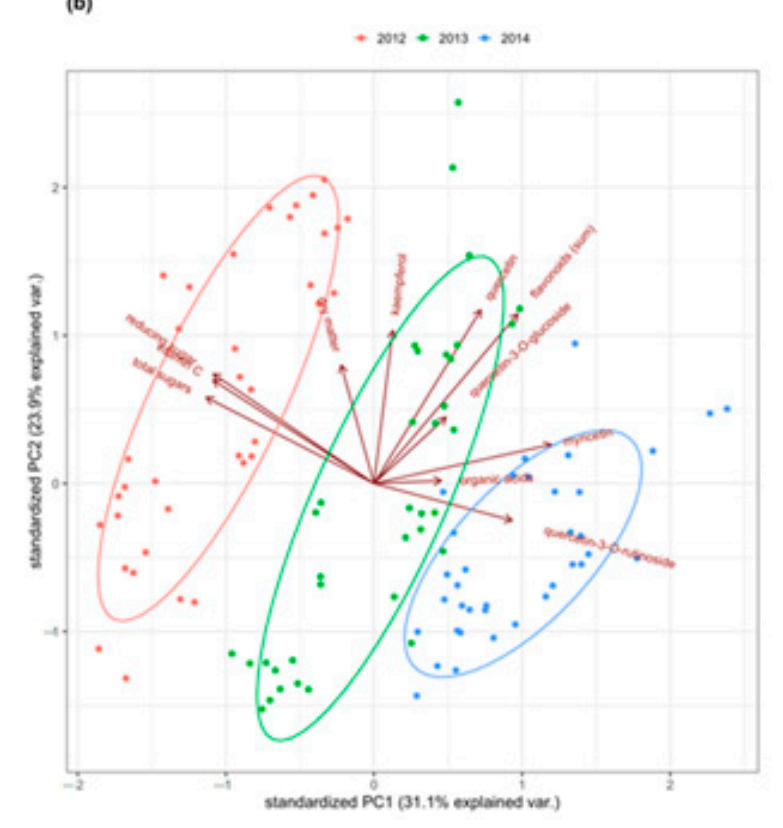

Figure 2. PCA biplot showing the relationships between the chemical composition of onion bulbs and (a) the studied fertilization treatments and (b) the cultivation seasons 2012, 2013, and 2014. Fertilization treatments: control N 0 (no input), control $\mathrm{N} 100$ (mineral fertilizer at $100 \mathrm{~kg} \mathrm{~N} \mathrm{ha}^{-1}$ ), control $\mathrm{N} 50+50$ (mineral fertilizer at $2 \times 50 \mathrm{~kg} \mathrm{~N}^{-1}$ ), Ekofert K 120/180/240 (red clover pellets at 120, 180, or $240 \mathrm{~kg} \mathrm{~N} \mathrm{ha}^{-1}$ ), Ekofert L 120/180/240 (alfalfa pellets at 120, 180, or $240 \mathrm{~kg} \mathrm{~N} \mathrm{ha}^{-1}$ ). PC1-the first principal component, PC2-the second principal component.

Two-factor ANOVA identified significant main effects for both the production season and fertilization for many composition parameters, but for most parameters, the differences between seasons were larger than the differences between fertilization treatments (Tables 2 and 3).

Table 2. The effect of cultivation season and fertilization regime on the content of dry matter, total sugars, reducing sugars, organic acids, and vitamin $C$ in onions. Data are presented as means \pm standard errors.

\begin{tabular}{|c|c|c|c|c|c|}
\hline Factor & Dry Matter $^{1}$ & Total Sugars ${ }^{1}$ & Reducing Sugars ${ }^{1}$ & Organic Acids ${ }^{1}$ & Vitamin $C^{2}$ \\
\hline \multicolumn{6}{|c|}{ Cultivation Season (CS) } \\
\hline 2012 & $13.4 \pm 0.2 \mathrm{a}^{3}$ & $10.58 \pm 0.20 \mathrm{a}$ & $3.52 \pm 0.10 \mathrm{a}$ & $0.22 \pm 0.01 \mathrm{~b}$ & $23.8 \pm 0.7 \mathrm{a}$ \\
\hline 2013 & $13.8 \pm 0.1 \mathrm{a}$ & $3.10 \pm 0.14 b$ & $2.19 \pm 0.07 b$ & $0.17 \pm 0.01 \mathrm{c}$ & $15.1 \pm 0.3 b$ \\
\hline 2014 & $12.8 \pm 0.1 \mathrm{~b}$ & $3.47 \pm 0.23 b$ & $2.04 \pm 0.04 \mathrm{~b}$ & $0.25 \pm 0.01 \mathrm{a}$ & $13.3 \pm 0.3 c$ \\
\hline \multicolumn{6}{|c|}{ Fertilization Regime (FR) ${ }^{4}$} \\
\hline control N 0 & $13.6 \pm 0.2$ & $5.79 \pm 1.27$ & $2.75 \pm 0.34$ & $0.23 \pm 0.01$ & $20.1 \pm 2.7$ \\
\hline control N 100 & $13.1 \pm 0.2$ & $5.20 \pm 1.17$ & $2.64 \pm 0.20$ & $0.22 \pm 0.01$ & $17.9 \pm 2.1$ \\
\hline control N $50+50$ & $13.2 \pm 0.5$ & $5.06 \pm 0.82$ & $2.71 \pm 0.14$ & $0.22 \pm 0.01$ & $17.8 \pm 1.3$ \\
\hline Ekofert K 120 & $13.0 \pm 0.2$ & $5.64 \pm 1.11$ & $2.20 \pm 0.15$ & $0.21 \pm 0.01$ & $18.2 \pm 1.5$ \\
\hline Ekofert K 180 & $13.2 \pm 0.2$ & $5.78 \pm 1.15$ & $2.46 \pm 0.19$ & $0.21 \pm 0.01$ & $16.6 \pm 1.4$ \\
\hline Ekofert K 240 & $13.7 \pm 0.3$ & $5.93 \pm 0.93$ & $2.57 \pm 0.23$ & $0.22 \pm 0.02$ & $18.3 \pm 1.3$ \\
\hline Ekofert L 120 & $13.3 \pm 0.2$ & $6.55 \pm 1.26$ & $2.58 \pm 0.15$ & $0.21 \pm 0.01$ & $16.0 \pm 0.7$ \\
\hline Ekofert L 180 & $13.6 \pm 0.2$ & $5.88 \pm 1.03$ & $2.58 \pm 0.30$ & $0.21 \pm 0.01$ & $16.5 \pm 1.4$ \\
\hline Ekofert L 240 & $13.3 \pm 0.1$ & $5.63 \pm 0.98$ & $2.74 \pm 0.32$ & $0.21 \pm 0.01$ & $15.2 \pm 0.7$ \\
\hline \multicolumn{6}{|l|}{ ANOVA $p$-values } \\
\hline CS & $<0.001$ & $<0.001$ & $<0.001$ & $<0.001$ & $<0.001$ \\
\hline FR & $\mathrm{NS}^{5}$ & 0.021 & 0.004 & NS & $<0.001$ \\
\hline $\mathrm{CS} \times \mathrm{FR}$ & $<0.001$ & $<0.001$ & $<0.001$ & 0.047 & $<0.001$ \\
\hline
\end{tabular}

${ }^{1} \mathrm{~g} 100 \mathrm{~g}^{-1}$ fresh weight; ${ }^{2} \mathrm{mg} 100 \mathrm{~g}^{-1}$ fresh weight; ${ }^{3}$ Values in columns followed by different letter (a-c) within each factor are significantly different at the $5 \%$ level of probability (Tukey's test); ${ }^{4}$ Fertilization: control 0 (no input), control NPK 100 (mineral fertilizer

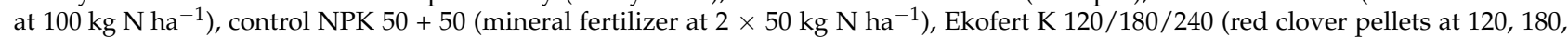
or $240 \mathrm{~kg} \mathrm{~N} \mathrm{ha}^{-1}$ ), Ekofert L 120/180/240 (alfalfa pellets at 120, 180, or $240 \mathrm{~kg} \mathrm{~N} \mathrm{ha}^{-1}$ ); ${ }^{5}$ Not significant. 
Table 3. The main effects of, and interactions between, cultivation season and fertilization regime on the content of flavonoids (mg $100 \mathrm{~g}^{-1}$ fresh weight) in onion. Data are presented as means \pm standard errors.

\begin{tabular}{|c|c|c|c|c|c|c|}
\hline Factor & $\begin{array}{l}\text { Flavonoids } \\
\quad \text { (Sum) }\end{array}$ & $\begin{array}{l}\text { Quercetin-3- } \\
\text { O-Rutinoside }\end{array}$ & $\begin{array}{l}\text { Quercetin-3- } \\
\text { O-Glucoside }\end{array}$ & Myricetin & Quercetin & Kaempferol \\
\hline \multicolumn{7}{|c|}{ Cultivation Season (CS) } \\
\hline 2012 & $44.2 \pm 1.8$ & $2.38 \pm 0.14 b^{1}$ & $10.6 \pm 0.2$ & $2.29 \pm 0.18 b$ & $24.8 \pm 1.3$ & $4.19 \pm 0.45 \mathrm{a}$ \\
\hline 2013 & $45.7 \pm 1.9$ & $2.44 \pm 0.13 b$ & $11.0 \pm 0.2$ & $2.35 \pm 0.18 b$ & $25.6 \pm 1.4$ & $4.35 \pm 0.47 \mathrm{a}$ \\
\hline 2014 & $49.0 \pm 1.1$ & $4.87 \pm 0.21 \mathrm{a}$ & $11.1 \pm 0.4$ & $4.89 \pm 0.29 \mathrm{a}$ & $25.3 \pm 0.7$ & $2.78 \pm 0.09 b$ \\
\hline \multicolumn{7}{|c|}{ Fertilization Regime (FR) $^{2}$} \\
\hline control N 0 & $46.2 \pm 1.7$ & $3.77 \pm 0.37$ & $11.4 \pm 0.7$ & $2.71 \pm 0.24$ & $25.4 \pm 1.5$ & $2.95 \pm 0.51$ \\
\hline control N 100 & $48.0 \pm 3.6$ & $3.34 \pm 0.35$ & $11.3 \pm 0.4$ & $3.24 \pm 0.52$ & $26.7 \pm 2.9$ & $3.38 \pm 0.21$ \\
\hline control N $50+50$ & $45.7 \pm 2.8$ & $3.00 \pm 0.34$ & $10.3 \pm 0.5$ & $2.51 \pm 0.27$ & $24.9 \pm 1.9$ & $5.02 \pm 0.57$ \\
\hline Ekofert K 120 & $43.3 \pm 2.7$ & $3.32 \pm 0.33$ & $10.7 \pm 0.3$ & $2.96 \pm 0.52$ & $21.6 \pm 1.2$ & $4.66 \pm 1.01$ \\
\hline Ekofert K 180 & $44.7 \pm 2.6$ & $2.89 \pm 0.28$ & $10.6 \pm 0.9$ & $4.52 \pm 1.02$ & $23.8 \pm 1.2$ & $2.86 \pm 0.22$ \\
\hline Ekofert K 240 & $46.1 \pm 3.7$ & $3.00 \pm 0.57$ & $10.8 \pm 0.3$ & $3.14 \pm 0.47$ & $26.3 \pm 3.1$ & $2.90 \pm 0.18$ \\
\hline Ekofert L 120 & $42.3 \pm 3.0$ & $3.08 \pm 0.42$ & $10.5 \pm 0.2$ & $2.86 \pm 0.49$ & $23.6 \pm 1.9$ & $2.31 \pm 0.39$ \\
\hline Ekofert L 180 & $44.9 \pm 2.8$ & $3.24 \pm 0.49$ & $11.5 \pm 0.4$ & $2.86 \pm 0.37$ & $24.5 \pm 1.7$ & $2.76 \pm 0.38$ \\
\hline Ekofert L 240 & $55.6 \pm 1.6$ & $3.45 \pm 0.71$ & $11.0 \pm 0.4$ & $3.78 \pm 0.27$ & $30.2 \pm 1.3$ & $7.11 \pm 0.88$ \\
\hline \multicolumn{7}{|l|}{ ANOVA $p$-values } \\
\hline CS & $\mathrm{NS}^{3}$ & $<0.001$ & NS & $<0.001$ & NS & $<0.001$ \\
\hline FR & NS & NS & NS & $<0.001$ & NS & $<0.001$ \\
\hline $\mathrm{CS} \times \mathrm{FR}$ & NS & 0.001 & 0.005 & $<0.001$ & NS & 0.003 \\
\hline
\end{tabular}

${ }^{1}$ Values in columns followed by different letters (a-c) within each factor are significantly different at the $5 \%$ level of probability (Tukey's test); ${ }^{2}$ Fertilization: control N 0 (no input), control N 100 (mineral fertilizer at $100 \mathrm{~kg} \mathrm{~N} \mathrm{ha}^{-1}$ ), control N $50+50$ (mineral fertilizer at $2 \times 50 \mathrm{~kg} \mathrm{~N} \mathrm{ha}^{-1}$ ), Ekofert K 120/180/240 (red clover pellets at 120, 180, or $240 \mathrm{~kg} \mathrm{~N} \mathrm{ha}^{-1}$ ), Ekofert L 120/180/240 (alfalfa pellets at 120, 180 , or $240 \mathrm{~kg} \mathrm{~N} \mathrm{ha}^{-1}$ ); ${ }^{3}$ Not significant.

However, contrasting overall trends of the season effect were observed for the different composition parameters (Tables 2 and 3). For example, while concentrations of total sugars, reducing sugars, and the flavonoid kaempferol were significantly higher in 2012 than 2014, concentrations of organic acids and the flavonoids quercetin-3-O-rutinoside and myricetin in onions were significantly higher in 2014 than in 2012 and 2013 (Tables 2 and 3).

The dry matter, organic acids, and sugar concentrations found in onion samples were within the ranges reported by other authors [37-40]. These parameters, and in particular the total soluble sugars content, contribute significantly to sensory quality and consumer acceptability of onions [40]. Overall, no consistent differences could be detected between fertilization treatments (Supplementary Figures S1-S3), although in 2012, the highest content of sugars (total) was observed in onions fertilized with Ekofert L at a rate of $120 \mathrm{~kg}$ $\mathrm{N} \mathrm{ha}^{-1}$ (Supplementary Figure S2).

As discussed by the authors of an extensive literature review, the content of dry matter in plant raw materials can be related to the type and doses of fertilizers used during the cultivation. The higher the dose of mineral fertilization, the more excessive vegetative growth, biomass development, and reduction of dry matter content in crops [41].

When the effect of fertilization treatments on concentrations of nutritionally desirable vitamin C and flavonoids was compared by two-factor ANOVA, no significant effect of fertilization and season was detected for total flavonoids (Table 3), while there was a highly significant interaction between season and fertilization for vitamin $C$ and all individual flavonoids except for quercetin (Tables 2 and 3 ).

When the significant interactions for vitamin $C$ and individual flavonoids were further investigated, each season showed contrasting trends for comparisons of (a) non-fertilized and fertilized crops, (b) single and split-dose mineral N-fertilization, (c) organic and mineral fertilizers, and (d) different organic fertilizer input levels (Supplementary Figures S6-S11).

The finding that there was no consistent effect of fertilizer type (organic vs. conventional) on phenolics and vitamin C content was unexpected, since meta-analyses of studies comparing the nutritional composition of organic and conventional crops have reported overall higher levels of phenolics and other antioxidants in organic compared to 
conventional crops [42,43]. However, it should be pointed out that the cited meta-analyses also identified a substantial variation between studies and crop types [42,43].

$\mathrm{N}$-availability to crop plants and irradiation were shown be the strong agronomic and environmental drivers for phenolic concentration in recent studies that compared the effect of organic and mineral fertilizers on phenolic levels in wheat $[44,45]$. However, in the study reported here, the $\mathrm{N}$-availability pattern could not be monitored, and we were therefore unable to investigate associations between this potential agronomic explanatory variable and phenolic levels.

Previous studies with wheat, grapes, and potatoes also showed that variety choice can be a major explanatory variable for phenolic concentrations [22,46,47]. For example, in a recent study with wheat, a variety from an organic farming-focused breeding program produced substantially higher flavonoid/phenolic levels with organic compared to mineral NPK fertilizers, while fertilizer types had only a small effect on flavonoid/phenolic concentrations in a variety from a conventional farming-focused breeding program [45]. In this context it is important to note that, in this study, a modern onion F1 hybrid developed for conventional farming systems was used.

Pests and disease attacks can also result in an increase in phenolic concentrations in plants, since phenolics are known to be a component of the plants inducible resistance response against biotrophic pests and diseases [48]. The interactions between season and fertilization treatments could therefore also have been due to differences in pest and disease incidence between seasons and/or fertilizer treatments. Higher pest and disease incidence has also been described as the main reason for higher levels of resistance-related phytochemical concentrations in organic compared to conventional crops [49], although there is virtually no experimental evidence $[44,45]$. In the study described here, no chemical plant protection was used in non-fertilized, mineral N, and Ekofert-fertilized plots, and this could also partly explain the lack of highly significant and consistent differences between the flavonoid content in onions grown with different fertilization regimes.

The range of vitamin $C$ contents in onion bulbs found in this study was similar to those reported previously by Tarrago-Trani et al. [50] and Elhassaneen [51]. Similarly, the concentrations and profile of the analyzed flavonoids in the tested onions were comparable to those reported by other authors $[40,52,53]$, with quercetin being a dominating flavonoid compound. Onion is known to contain one of the highest levels of quercetin among vegetables and fruits [52].

Overall, the results from this study suggest that onions produce similar or slightly higher yields with organic Ekofert when compared to mineral $\mathrm{N}$ fertilization regimes used in conventional farming, while there was no consistent effect of fertilization on the sensory and nutritional composition parameters assessed.

The concentrations of bioactive compounds such as phenolics in plants is very variable, not only depending on the climate, other production conditions and practices, but also on the plant genotype or post-harvest handling $[54,55]$. The results obtained in this study and reported by other authors indicate that there is still a need for further research to identify the best practices and plant genotypes to guarantee high levels of health-promoting bioactive compounds in the crops.

\subsection{Associations between Composition Parameters}

Pearson's correlation analysis identified a range of significant positive and negative correlations between the composition parameters assessed in onion bulb samples (Figure 3). Most importantly, there were strong positive correlations between total sugar and (a) total flavonoid $(r=0.94, p<0.001)$ and (b) vitamin $C$ content $(r=0.62, p<0.001)$ in onion bulbs. If confirmed in future studies, this would suggests that a sweet taste may also indicate a high content of nutritionally desirable vitamin $C$ and flavonoids. Other authors $[56,57]$ have also reported positive significant correlations between sugar content and levels of phenolics and vitamin $C$ in nectarine fruits. In the case of phenolic compounds, it can be explained by the function of sugars in the regulation of biosynthesis of polyphenols [56]. 
A positive correlation between sugars and vitamin $C$ content in onions could result from the fact that soluble carbohydrates are precursors to vitamin $C$, and when the plant produces more sugars through photosynthesis, it synthesizes more vitamin C [58].

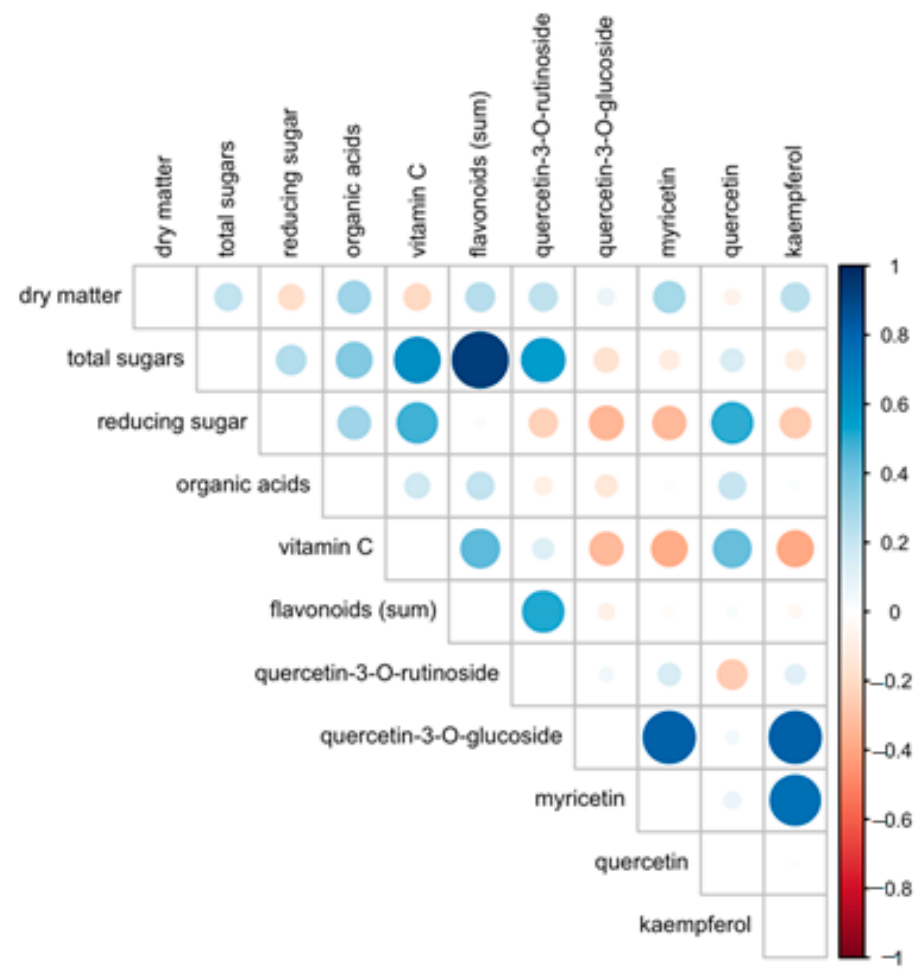

Figure 3. Pearson's correlations between the concentrations of the analyzed compounds identified in onion bulb samples. Color (red/blue) and the color intensity indicate the direction and the strength of the association, while the size of the circle reflects the statistical significance of the correlation ( $p$-value).

A strong positive correlation was also found between the content of quercetin-3-Oglucoside and myricetin and kaempferol, as well as between myricetin and kaempferol $(\mathrm{r}=0.81, p<0.001)$. This could be explained by the synthesis and/or metabolism of these compounds being closely linked and/or regulated by the same environmental and agronomic drivers. Quercetin, together with kaempferol and myricetin, belong to the class of flavonols, which are an important subfamily of flavonoids, and have the same dihydro precursors in biosynthesis process [59]. Kaempferol is a substrate for myricetin synthesis, and dihydrokaempferol is a substrate for generating dihydroquercetin, which finally is transformed to quercetin $[59,60]$.

\section{Conclusions}

The results from this study show that onions produce similar or slightly higher yields with organic Ekofert when compared to mineral $\mathrm{N}$ fertilization regimes. At the same time, the consistent effect of fertilization on the studied sensory and nutritional composition parameters was not identified. Cultivation season appeared to be a predominant factor influencing the measured onion composition variables. Moreover, in the case of majority of the studied parameters, highly significant interactions between season and fertilization regimes were found, which means that the effects of fertilization regimes depended on the cultivation season.

The finding that the organic fertilizers made from legume crops (Ekofert $\mathrm{K}$ and Ekofert L) delivered similar yields to mineral $\mathrm{N}$ fertilizers is of substantial commercial significance for the organic horticultural crop production sector. This is mainly because there is a shortage of organic fertilizers with a high nitrogen content that can be applied prior to planting. However, since these fertilizers can be produced from fertility-building legume 
crops on stockless organic farms, the use of this type of fertilizer could also potentially help to limit the amount of fertilizer that needs to be imported onto specialist, stockless farms. This would improve self-sufficiency and sustainability of stockless systems in line with organic farming principles.

Literature sources indicate that the optimization of crop production methods and several pre- and post-harvest practices are among the essential steps to obtain expected high levels of health-promoting phytochemicals in vegetables and fruits. Thus, searching for innovative solutions, such as effective organic fertilizers that are productive and beneficial for the environment, and combining them with agronomic practices ensuring high healthpromoting qualities of the crops, is of great importance.

Supplementary Materials: The following are available online at https:/ / www.mdpi.com/article/10 .3390 /agronomy11050883/s1, Figure S1: Dry matter in onion bulbs of Alonso F1 cultivar grown in organic and conventional fertilization regimes in three years of cultivation, Figure S2: Total sugars content in onion bulbs of Alonso F1 cultivar grown in organic and conventional fertilization regimes in three years of cultivation, Figure S3: Reducing sugars content in onion bulbs of Alonso F1 cultivar grown in organic and conventional fertilization regimes in three years of cultivation, Figure S4: Organic acids content in onion bulbs of Alonso F1 cultivar grown in organic and conventional fertilization regimes in three years of cultivation, Figure S5: Vitamin C content in onion bulbs of Alonso F1 cultivar grown in organic and conventional fertilization regimes in three years of cultivation, Figure S6: Flavonoids (sum) content in onion bulbs of Alonso F1 cultivar grown in organic and conventional fertilization regimes in three years of cultivation, Figure S7: Quercetin-3-Oglucoside content in onion bulbs of Alonso F1 cultivar grown in organic and conventional fertilization regimes in three years of cultivation, Figure S8: Quercetin-3-O-rutinoside content in onion bulbs of Alonso F1 cultivar grown in organic and conventional fertilization regimes in three years of cultivation, Figure S9: Myricetin content in onion bulbs of Alonso F1 cultivar grown in organic and conventional fertilization regimes in three years of cultivation, Figure S10: Quercetin content in in onion bulbs of Alonso F1 cultivar grown in organic and conventional fertilization regimes in three years of cultivation, Figure S11: Kaempferol content in onion bulbs of Alonso F1 cultivar grown in organic and conventional fertilization regimes in three years of cultivation.

Author Contributions: Conceptualization, R.K., E.H., E.R., J.G., and S.K.; Data curation, R.K., D.Ś.-T., M.B., E.H., K.K., J.G., and S.K.; Formal analysis, R.K., E.H., and J.G.; Funding acquisition, D.S.-T., C.L., and S.K.; Investigation, R.K., D.Ś.-T., M.B., R.G.-W., and S.K.; Methodology, R.K., D.Ś.-T., M.B., E.H., and S.K.; Supervision, R.K. and D.Ś.-T.; Visualization, R.K., D.Ś.-T., M.B., and K.K.; Writing-original draft, R.K., D.Ś.-T., M.B., R.G.-W., C.L., and L.R.; Writing-review and editing, R.K., D.Ś.-T., M.B., R.G.-W., C.L., and L.R. All authors have read and agreed to the published version of the manuscript.

Funding: The study was conducted with the contribution of the LIFE+ financial instrument of the EU and co-financed by the National Fund for Environmental Protection and Water Management (grant number LIFE10 ENV/PL/661). The onion composition analyses were funded by the Polish Ministry of Science and Higher Education with funds of the Institute of Human Nutrition Sciences, Warsaw University of Life Sciences (WULS) for scientific research. The article processing charges were covered with a grant from the Financial Support System for Scientists and Research Teams in the Warsaw University of Life Sciences (awarded in 2020 to D.Ś.-T., grant number 504-02-780400-S00123-99).

Institutional Review Board Statement: Not applicable.

Informed Consent Statement: Not applicable.

Data Availability Statement: Data will be made available upon reasonable request by authors Renata Kazimierczak and Dominika Średnicka-Tober.

Acknowledgments: We gratefully acknowledge the technical support of Tomasz Strok in the preparation of onion bulb samples and the support of Alicja Ponder in critical reading of the manuscript.

Conflicts of Interest: The authors declare no conflict of interest. The funders had no role in the design of the study, in the collection, analyses, or interpretation of data, in the writing of the manuscript, or in the decision to publish the results. 


\section{References}

1. Gebska, M.; Grontkowska, A.; Swiderek, W.; Golebiewska, B. Farmer awareness and implementation of sustainable agriculture practices in different types of farms in Poland. Sustainability 2020, 12, 8022. [CrossRef]

2. Tahat, M.M.; Alananbeh, K.M.; Othman, Y.A.; Leskovar, D.I. Soil health and sustainable agriculture. Sustainability 2020, $12,4859$. [CrossRef]

3. Krull, E.S.; Skjemstad, J.O.; Baldock, J.A. Functions of soil organic matter and the effect on soil properties. In Grains Research $\mathcal{E}$ Development Corporation Project No CSO 00029; CSIRO Land \& Water: Glen Osmond, Australia, 2009; ISBN 0957959745.

4. Leifert, C.; Ball, K.; Volakakis, N.; Cooper, J.M. Control of enteric pathogens in ready-to-eat vegetable crops in organic and "low input" production systems: A HACCP-based approach. J. Appl. Microbiol. 2008, 105, 931-950. [CrossRef] [PubMed]

5. Nygaard Sørensen, J.; Thorup-Kristensen, K. Plant-based fertilizer for organic production. Acta Hortic. 2010, 852, 195-200. [CrossRef]

6. Baslam, M.; Mitsui, T.; Sueyoshi, K.; Ohyama, T. Recent advances in carbon and nitrogen metabolism in C3 plants. Int. J. Mol. Sci. 2021, 22, 1-39.

7. Nicastro, H.L.; Ross, S.A.; Milner, J.A. Garlic and onions: Their cancer prevention properties. Cancer Prev. Res. 2015, 8, 181-189. [CrossRef]

8. Shade, J.; Cattell Noll, L.; Seufert, V.; Galloway, J.N.; Erisman, J.W. Decreasing reactive nitrogen losses in organic agricultural systems. Org. Agric. 2020. [CrossRef]

9. Quemada, M.; Baranski, M.; Nobel-de Lange, M.N.J.; Vallejo, A.; Cooper, J.M. Meta-analysis of strategies to control nitrate leaching in irrigated agricultural systems and their effects on crop yield. Agric. Ecosyst. Environ. 2013, 174, 1-10. [CrossRef]

10. Bettoni, M.M.; Mogor, Á.F.; Pauletti, V.; Goicoechea, N.; Aranjuelo, I.; Garmendia, I. Nutritional quality and yield of onion as affected by different application methods and doses of humic substances. J. Food Compos. Anal. 2016, 51, 37-44. [CrossRef]

11. Griffiths, G.; Trueman, L.; Crowther, T.; Thomas, B.; Smith, B. Onions-A global benefit to health. Phyther. Res. 2002, 16, 603-615. [CrossRef]

12. Banerjee, S.K.; Maulik, S.K. Effect of garlic on cardiovascular disorders: A review. Nutr. J. 2002, 1, 1-14. [CrossRef] [PubMed]

13. Wilson, E.A.; Demmig-Adams, B. Antioxidant, anti-inflammatory, and antimicrobial properties of garlic and onions. Nutr. Food Sci. 2007, 37, 178-183. [CrossRef]

14. Rauf, A.; Imran, M.; Khan, I.A.; Ur-Rehman, M.; Gilani, S.A.; Mehmood, Z.; Mubarak, M.S. Anticancer potential of quercetin: A comprehensive review. Phyther. Res. 2018, 32, 2109-2130. [CrossRef] [PubMed]

15. Shahidi, F.; Yeo, J.D. Bioactivities of phenolics by focusing on suppression of chronic diseases: A review. Int. J. Mol. Sci. 2018, 19, 1573. [CrossRef]

16. Valko, M.; Leibfritz, D.; Moncol, J.; Cronin, M.T.D.; Mazur, M.; Telser, J. Free radicals and antioxidants in normal physiological functions and human disease. Int. J. Biochem. Cell Biol. 2007, 39, 44-84. [CrossRef]

17. Ahn-Jarvis, J.H.; Parihar, A.; Doseff, A.I. Dietary flavonoids for immunoregulation and cancer: Food design for targeting disease. Antioxidants 2019, 8, 202. [CrossRef]

18. Burns, J. Phenolic Antioxidants in Red Wine: Content and Activity; University of Glasgow: Glasgow, UK, 2000.

19. Huyut, Z.; Beydemir, Ş.; Gülçin, I. Antioxidant and antiradical properties of selected flavonoids and phenolic compounds. Biochem. Res. Int. 2017, 2017, 1-10. [CrossRef]

20. Kumar, S.; Pandey, A.K. Chemistry and biological activities of flavonoids: An overview. Science 2013, 2013, 162750. [CrossRef]

21. Carbone, F.; Preuss, A.; De Vos, R.C.H.; D’Amico, E.; Perrotta, G.; Bovy, A.G.; Martens, S.; Rosati, C. Developmental, genetic and environmental factors affect the expression of flavonoid genes, enzymes and metabolites in strawberry fruits. Plant Cell Environ. 2009, 32, 1117-1131. [CrossRef]

22. Kazimierczak, R.; Srednicka-Tober, D.; Hallmann, E.; Kopczynska, K.; Zarzynska, K. The impact of organic vs. conventional agricultural practices on selected quality features of eight potato cultivars. Agronomy 2019, 9, 799. [CrossRef]

23. Hallmann, E.; Kazimierczak, R.; Marszałek, K.; Drela, N.; Kiernozek, E.; Toomik, P.; Matt, D.; Luik, A.; Rembiałkowska, E. The nutritive value of organic and conventional white cabbage (Brassica oleracea L. var. Capitata) and anti-apoptotic activity in gastric adenocarcinoma cells of sauerkraut juice produced therof. J. Agric. Food Chem. 2017, 65, 8171-8183. [CrossRef]

24. Hoehn, E.; Gasser, F.; Guggenbühl, B.; Künsch, U. Efficacy of instrumental measurements for determination of minimum requirements of firmness, soluble solids, and acidity of several apple varieties in comparison to consumer expectations. Postharvest Biol. Technol. 2003, 27, 27-37. [CrossRef]

25. Kazimierczak, R.; Hallmann, E.; Lipowski, J.; Drela, N.; Kowalik, A.; Püssa, T.; Matt, D.; Luik, A.; Gozdowskif, D.; Rembiałkowska, E. Beetroot (Beta vulgaris L.) and naturally fermented beetroot juices from organic and conventional production: Metabolomics, antioxidant levels and anticancer activity. J. Sci. Food Agric. 2014, 94, 2618-2629. [CrossRef]

26. Hallmann, E. The influence of organic and conventional cultivation systems on the nutritional value and content of bioactive compounds in selected tomato types. J. Sci. Food Agric. 2012, 92, 2840-2848. [CrossRef]

27. Harris, R. An Introduction to R. Quant. Geogr. Basics 2018, 3, 250-286.

28. Pinheiro, J.C.; Bates, D.M. Mixed-Effects Models in S and S-PLUS; Springer: New York, NY, USA, 2000.

29. Hothorn, T.; Bretz, F.; Westfall, P. Simultaneous inference in general parametric models. Biom. J. 2008, 50, 346-363. [CrossRef] [PubMed] 
30. Kandil, A.A.; Sharief, A.E.; Fathalla, F.H. Effect of organic and mineral fertilizers on vegetative growth, bulb yield and quality of onion cultivars. Esci J. Crop Prod. 2013, 2, 91-100.

31. Yoldas, F.; Ceylan, S.; Mordogan, N.; Esetlili, B.C. Effect of organic and inorganic fertilizers on yield and mineral content of onion (Allium cepa L.). Afr. J. Biotechnol. 2011, 10, 11488-11492.

32. Al-Fraihat, A.H. Impact of different fertilizer sources on vegetative growth, yield, quality and storability of onion. Int. Invent. Yournal Agric. Soil Sci. 2016, 4, 1-8.

33. Gererufael, L.A.; Abraham, N.T.; Reda, T.B. Growth and yield of onion (Allium cepa L.) as affected by farmyard manure and nitrogen fertilizer application in Tahtay Koraro District, Northwestern Zone of Tigray, Ethiopia. Vegetos 2020, 33, 617-627. [CrossRef]

34. Kaniszewski, S.; Babik, I.; Babik, J. Pelletized legume plants as fertilizer for vegetables in organic farming. In Proceedings of the NUTRIHORT: Nutrient Management, Innovative Techniques and Nutrient Legislation in Intensive Horticulture for an Improved Water Quality, Ghent, Belgium, 16-18 September 2013; D’Haene, K., Vandecasteele, B., De Vis, R., Crappé, S., Callens, D., Mechant, E., Hofman, G., De Neve, S., Eds.; Institute for Agricultural and Fisheries Research: Merelbeke, Belgium, 2013 ; pp. 330-336.

35. Yassen, A.A.; Khalid, K.A. Influence of organic fertilizers on the yield, essential oil and mineral content of onion. Int. Agrophysics 2009, 23, 183-188.

36. Spiess, E.; Prasuhn, V.; Stauffer, W. Einfluss von organischer und mineralischer Düngung auf die Nährstoffauswaschung. Agrar. Schweiz 2011, 2, 376-381.

37. Milan, M.B.; Dejan, U.; Nenad, C. Onion yield and yield contributing characters as affected by organic fertilizers. F. Veg. Crop. Res. 2011, 48, 341-346.

38. Bogevska, Z.; Agic, R.; Skopje, F.; Popsimonova, G. Reducing and total sugar content in onion during storage in the republic of Macedonia. Агрозна 2016, 17, 37-46. [CrossRef]

39. Malik, G.; Shabir, A.; Shah, R.A.; Nissar, R.; Masoodi, L.; Selvakumar, R.; Nabi, S.U.; Kirmani, S.N. Sugars and pungency of different day length adapted onions (Allium cepa L.) grown in long day temperate climate of Kashmir valley. Int. J. Chem. Stud. 2020, 8, 3790-3794. [CrossRef]

40. Liguori, L.; Califano, R.; Albanese, D.; Raimo, F.; Crescitelli, A.; Di Matteo, M. Chemical composition and antioxidant properties of five white onion (Allium cepa L.) landraces. J. Food Qual. 2017, 2017, 6873651. [CrossRef]

41. Stefanelli, D.; Goodwin, I.; Jones, R. Minimal nitrogen and water use in horticulture: Effects on quality and content of selected nutrients. Food Res. Int. 2010, 43, 1833-1843. [CrossRef]

42. Barański, M.; Średnicka-Tober, D.; Volakakis, N.; Seal, C.; Sanderson, R.; Stewart, G.B.; Benbrook, C.; Biavati, B.; Markellou, E.; Giotis, C.; et al. Higher antioxidant and lower cadmium concentrations and lower incidence of pesticide residues in organically grown crops: A systematic literature review and meta-analyses. Br. J. Nutr. 2014, 112, 794-811. [CrossRef]

43. Brandt, K.; Srednicka-Tober, D.; Barański, M.; Sanderson, R.; Leifert, C.; Seal, C. Methods for comparing data across differently designed agronomic studies: Examples of different meta-analysis methods used to compare relative composition of plant foods grown using organic or conventional production methods and a protocol for a systemati. J. Agric. Food Chem. 2013, 61, 7173-7180. [CrossRef] [PubMed]

44. Rempelos, L.; Almuayrifi, A.M.; Baranski, M.; Tetard-Jones, C.; Eyre, M.; Shotton, P.; Cakmak, I.; Ozturk, L.; Cooper, J.; Volakakis, N.; et al. Effects of agronomic management and climate on leaf phenolic profiles, disease severity, and grain yield in organic and conventional wheat production systems. J. Agric. Food Chem. 2018, 66, 10369-10379. [CrossRef]

45. Rempelos, L.; Almuayrifi, M.S.B.; Baranski, M.; Tetard-Jones, C.; Barkla, B.; Cakmak, I.; Ozturk, L.; Cooper, J.; Volakakis, N.; Hall, G.; et al. The effect of agronomic factors on crop health and performance of winter wheat varieties bred for the conventional and the low input farming sector. F. Crop. Res. 2020, 254, 107822. [CrossRef]

46. Hasanaliyeva, G.; Chatzidimitrou, E.; Wang, J.; Baranski, M.; Volakakis, N.; Pakos, P.; Seal, C.; Rosa, E.A.S.; Markellou, E.; Iversen, P.O.; et al. Effect of organic and conventional production methods on fruit yield and nutritional quality parameters in three traditional cretan grape varieties: Results from a farm survey. Foods 2021, 10, 476. [CrossRef]

47. Hasanaliyeva, G.; Chatzidimitrou, E.; Wang, J.; Baranski, M.; Volakakis, N.; Seal, C.; Rosa, E.A.S.; Iversen, P.O.; Vigar, V.; Barkla, B.; et al. Effects of production region, production systems and grape type/variety on nutritional quality parameters of table grapes; results from a UK retail survey. Foods 2020, 9, 1874. [CrossRef] [PubMed]

48. Margaritopoulou, T.; Toufexi, E.; Kizis, D.; Balayiannis, G.; Anagnostopoulos, C.; Theocharis, A.; Rempelos, L.; Troyanos, Y.; Leifert, C.; Markellou, E. Reynoutria sachalinensis extract elicits SA-dependent defense responses in courgette genotypes against powdery mildew caused by Podosphaera xanthii. Sci. Rep. 2020, 10, 3354. [CrossRef]

49. Wegener, C.; Jansen, G.; Jurgens, H.-U. Influence of drought and wounding stress on soluble phenols and proteins in potato tubers. Sustain. Agric. Res. 2014, 3. [CrossRef]

50. Tarrago-trani, M.T.; Phillips, K.M.; Cotty, M. Matrix-specific method validation for quantitative analysis of vitamin C in diverse foods. J. Food Compos. Anal. 2012, 26, 12-25. [CrossRef]

51. Elhassaneen, Y.A.; Sanad, M.I. Phenolics, selenium, vitamin C, amino acids and pungency levels and antioxidant activities of two egyptian onion varieties. Am. J. Food Technol. 2009, 4, 241-254. [CrossRef]

52. Ren, F.; Reilly, K.; Kerry, J.P.; Gaffney, M.; Hossain, M.; Rai, D.K. Higher antioxidant activity, total flavonols, and specific quercetin glucosides in two different onion (Allium cepa L.) varieties grown under organic production: Results from a 6-year field study. J. Agric. Food Chem. 2017, 65, 5122-5132. [CrossRef] 
53. Slimestad, R.; Fossen, T.; Vågen, I.M. Onions: A source of unique dietary flavonoids. J. Agric. Food Chem. 2007, 55, 10067-10080. [CrossRef]

54. Tiwari, U.; Cummins, E. Factors influencing levels of phytochemicals in selected fruit and vegetables during pre- and post-harvest food processing operations. Food Res. Int. 2013, 50, 497-506. [CrossRef]

55. Reilly, K.; Valverde, J.; Finn, L.; Gaffney, M.; Rai, D.K.; Brunton, N. A note on the effectiveness of selenium supplementation of Irish-grown Allium crops. Ir. J. Agric. Food Res. 2014, 53, 91-99.

56. Abidi, W.; Jiménez, S.; Moreno, M.Á.; Gogorcena, Y. Evaluation of antioxidant compounds and total sugar content in a nectarine [Prunus persica (L.) Batsch] progeny. Int. J. Mol. Sci. 2011, 12, 6919-6935. [CrossRef] [PubMed]

57. Font i Forcada, C.; Oraguzie, N.; Igartua, E.; Moreno, M.; Gogorcena, Y. Population structure and marker-trait associations for pomological traits in peach and nectarine cultivars. Tree Genet. Genomes 2013, 9, 331-349. [CrossRef]

58. Paciolla, C.; Fortunato, S.; Dipierro, N.; Paradiso, A.; De Leonardis, S.; Mastropasqua, L.; de Pinto, M.C. Vitamin C in plants: From functions to biofortification. Antioxid 2019, 8, 519. [CrossRef]

59. Marín, L.; Gutiérrez-Del-Río, I.; Entrialgo-Cadierno, R.; Villar, C.J.; Lombó, F. De novo biosynthesis of myricetin, kaempferol and quercetin in Streptomyces albus and Streptomyces coelicolor. PLoS ONE 2018, 13, e0207278. [CrossRef]

60. Crozier, A.; Jaganath, I.B.; Clifford, M.N. Dietary phenolics: Chemistry, bioavailability and effects on health. Nat. Prod. Rep. 2009, 26, 1001-1043. [CrossRef] 